\title{
KEMAMPUAN PEREMPUAN TANI DALAM MENDUKUNG KETAHANAN PANGAN RUMAH TANGGA
}

\author{
Hayati $^{1}$, Siti Amanah ${ }^{2}$., Aida Vitayala Hubeis ${ }^{3}$, dan Prabowo Tjitropanoto ${ }^{4}$ \\ ${ }^{1}$ Fakultas Pertanian Universitas Mataram \\ 2,3,4 Departemen Komunikasi dan Pengembangan Masyarakat FEMA, IPB \\ E-mail: hayatizakaria75@yahoo.com
}

\begin{abstract}
ABSTRAK. Perempuan tani di Kabupaten Lombok Timur berperan intensif dalam produksi, pengolahan, penyiapan dan pendistribusian pangan keluarga, namun kualitas konsumsi pangan rumah tangga masih rendah. Penelitian ini bertujuan untuk mendiskripsikan dan menganalisis faktor yang berhubungan dengan kemampuan perempuan tani, dan menganalisis kemampuan perempuan tani mewujudkan ketahanan pangan rumah tangga. Penelitian menggunakan metode penelitian survei dengan jumlah sampel sebanyak 300 rumah tangga yang tersebar di Kecamatan Terara dan Aikmel Kabupaten Lombok Timur. Data primer diperoleh melalui wawancara terstruktur dengan menggunakan kuesioner, wawancara mendalam, pengamatan. Hasil penelitian menunjukkan bahwa karakteristik pribadi perempuan tani kuat dalam hal kematangan dan motivasi, namun lemah dalam pendidikan formal dan non formal. Perempuan tani dominan dalam pengambilan keputusan rumah tangga tetapi rendah pendapatannya. Perempuan tani tidak mendapatkan dukungan sosial budaya, dan terbatasnya akses terhadap sumber daya produktif. Secara umum, dukungan penyuluhan terhadap perempuan tani dalam mewujudkan ketahanan pangan rumah tangga juga lemah. Tingkat kemampuan perempuan tani secara teknis lebih baik daripada secara manajerial dan sosial rendah. Kemampuan perempuan tani dalam mendukung ketahanan pangan rumah tangga berhubungan positif dan nyata dengan pendidikan non formal, motivasi, tanggungan keluarga, luas lahan, keputusan, akses sumberdaya dan penyuluhan. Untuk itu, diperlukan penyuluhan ketahanan pangan yang intensif dan spesifik bagi perempuan tani.
\end{abstract}

Kata kunci: perempuan tani, kemampuan, extension, ketahanan pangan rumah tangga

\section{WOMEN CAPACITY TO SUPPORT FARMER HOUSEHOLD FOOD SECURITY}

\begin{abstract}
Eventhough women's farmer in East Lombok District involve intensively in production, processing, preparation and distribution of family's food, but the status of household's food consumption is low. This study aims to analyze the capacity of women's farmer to support household food security. This research applied the survey method that took place in four villages of two sub-districts in East Lombok Districts, with 300 housewife as respondents. The results showed that the personal characteristics of women's farmer show maturity and motivation, but weak in the formal and non-formal education. Women's farmer have dominant role in decision-making but lack of income; have limited access to resources; have lack supported of social culture and extension; have better the level of technical capacity than managerial and social. The capacity of women's farmer related positively and significantly with non-formal education, motivation, family size, land size, decision making, access to resources and extension. This requires specifically and intensive extension for women's farmer.
\end{abstract}

Key words: women's farmer, capacity, household food security, extension

\section{PENDAHULUAN}

Perempuan tani, umumnya berpartisipasi dalam kegiatan ketahanan pangan baik pada aspek ketersediaan, akses, maupun pemanfaatan pangan. Perempuan tani berperan strategis untuk memenuhi kebutuhan pangan dan gizi rumah tangga. Perempuan tani dalam budaya Timur melakukan pemilihan bahan makanan, pengelolaan hingga mengolah dan menyediakannya bagi anggota rumah tangga (Arumsari dan Rini 2008). Peran strategis ini perlu diiringi dengan perilaku yang mendukung terwujudnya ketahanan pangan rumah tangga. Perilaku itu ditentukan oleh profil sosial ekonomi, sosial budaya yang bisa saja berbeda antara satu orang dengan lainnya, seperti yang ditemukan Yunita (2011) pada petani sawah lebak di Sumatera Selatan, Damanik (2014) pada pengolah sagu di Maluku.

Perilaku perempuan tani di Kabupaten Lombok Timur belum mendukung untuk mewujudkan ketahanan pangan rumah tangga. Perempuan tani cenderung mencontoh perilaku pendahulu/orang tua dalam hal pangan rumah tangga. Kondisi itu memengaruhi kualitas konsumsi pangan rumah tangga. Rendahnya kualitas konsumsi pangan masyarakat di Kabupaten Lombok Timur pada tahun 2011 terlihat dari capaian pola pangan harapan (PPH) yang rendah (76.66 persen) dan rata-rata asupan energi harian yang masih di bawah standar nasional yaitu $1956 \mathrm{kkal} / \mathrm{kapita} / \mathrm{hari}$. Diperlukan perubahan perilaku perempuan tani di Kabupaten Lombok Timur yang dilakukan melalui penyuluhan mengenai aspek ketersediaan, akses, dan pemanfaatan pangan sehingga kemampuan perempuan tani menguat dan kesejahteraan rumah tangga meningkat (Sumardjo 1999). Firmansyah et al. (2010) menemukan rendahnya kualitas konsumsi pangan berdampak terhadap rendahnya kualitas sumber daya manusia. Kondisi ini tidak sejalan dengan Undang-undang No 18 Tahun 2012 tentang Pangan yang menyebutkan bahwa pemenuhan hak asasi manusia dalam hal pangan merupakan kebutuhan dasar manusia yang paling utama dan dijamin di dalam 
Undang-Undang Dasar Negara Republik Indonesia Tahun 1945 sebagai landasan untuk mewujudkan sumber daya manusia yang berkualitas.

Penelitianinibertujuanuntuk:(1)mendeskripsikan dan menganalisis karakteristik pribadi perempuan tani, sosial ekonomi rumah tangga, sosial budaya masyarakat, akses perempuan tani terhadap sumber daya produktif, dukungan penyuluhan bagi perempuan tani; (2) mendeskripsikan dan menganalisis tingkat kemampuan kemampuan perempuan tani yang terdiri dari teknis, manajerial dan sosial yang dimiliki perempuan tani; dan (3) menganalisis hubungan faktor-faktor terkait dengan tingkat kemampuan teknis, manajerial, dan sosial yang dimiliki perempuan tani dalam mendukung ketahanan pangan rumah tangga tani.

\section{METODE}

Penelitian dilakukan di Desa Terara dan Desa Rarang Selatan yang mewakili Kecamatan Terara serta Desa Aikmel dan Desa Lenek Pasiraman yang mewakili Kecamatan Aikmel di Kabupaten Lombok Timur. Populasi penelitian 4.123 rumah tangga, sampel penelitian adalah perempuan tani (istri atau kepala keluarga) dari 300 rumah tangga yang ditentukan secara acak proporsional dengan metode Slovin. Pengambilan data primer dilakukan melalui wawancara terstruktur dengan menggunakan kuesioner, wawancara terbuka, dan pengamatan. Variabel penelitian terdiri dari: karakteristik pribadi perempuan tani (X1), sosial ekonomi rumah tangga (X2), sosial budaya masyarakat (X3), akses terhadap sumber daya produktif (X4), dukungan pelaksanaan penyuluhan (X5), tingkat kemampuan perempuan tani (Y1). Data sekunder dikumpulkan dari instansi terkait terkait dengan pangan rumah tangga. Pengujian instrumen menghasilkan nilai yang valid ( $\mathrm{r}$ hitung $=0.306-0.963>\mathrm{r} 0.05=0.361$ ) dan reliabel (nilai cronbach alpha $=0.610-0.997$ ). Data yang diperoleh diskoring dan ditransformasi menjadi skala 0 sampai 100 untuk mempermudah melakukan perbandingan antar variabel. Analisis data menggunakan statistik deskriptif dan inferensial korelasi Pearson dengan menggunakan program Statistical Product and Service Solution (SPSS) versi 18.

\section{HASIL DAN PEMBAHASAN}

\section{Karakteristik Pribadi Perempuan tani}

Sebanyak 65.7 persen perempuan tani termasuk dalam kategori dewasa awal (Gambar 1) yang menurut Hurlock(2001) perempuan tanimemikul tanggungjawab yang besar dalam memelihara keluarga. Dalam konteks ketahanan pangan, perempuan tani bertugas agar dirinya dan semua anggota rumah tangganya memperoleh pangan yang berkualitas agar dapat tumbuh sehat dan aktif. Persoalannya, tingkat pendidikan perempuan tani belum mendukung ke arah itu. Umumnya perempuan tani tergolong tidak pernah sekolah, tidak tamat dan tamat SD. Sebuah kondisi yang umum dialami perempuan tani Indonesia (Ariningsih dan Rachman 2008). Rendahnya akses, minat pada masa usia sekolah, kesadaran orang tua akan pentingnya pendidikan bagi anak perempuan tani, dan ada pandangan masyarakat bahwa perempuan tani tidak perlu bersekolah tinggi, merupakan beberapa faktor penyebabnya. Rataan lama sekolah bagi perempuan tani yang 4 tahun adalah lebih rendah daripada laki-laki (6.6 tahun).

Perempuan tani memiliki akses terbatas terhadap pendidikan non formal ( 90.3 persen). Dari 300 rumah tangga, hanya 18 persen perempuan tani pernah mengikuti penyuluhan dari Penyuluh Pertanian Lapangan (PPL), penyuluh swadaya, kader posyandu, dan petugas dari Puskesmas.

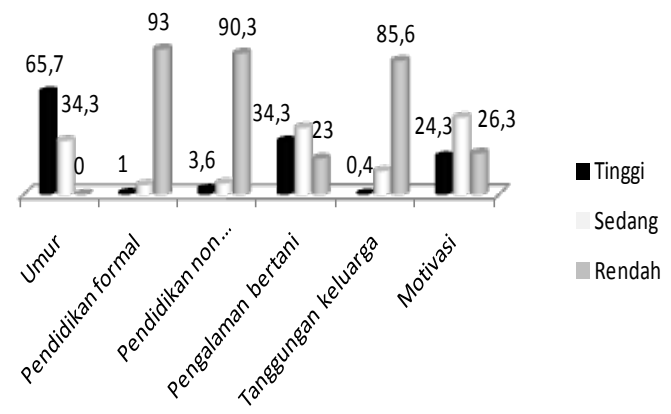

Gambar 1. Sebaran perempuan tani menurut karakteristik pribadi di Kabupaten Lombok Timur

Materi yang disampaikan PPL dominan tentang aspek produksi pangan saja. PPL belum memahami bahwa aspek ketersediaan, akses dan pemanfaatan pangan merupakan satu kesatuan dan saling berhubungan. Hal ini mendukung pernyataan Suprapto (2010) bahwa penyuluh pertanian hanya memahami aspek produksinya saja sedangkan aspek distribusi dan aspek gizi masih rendah. PPL juga memiliki pandangan yang keliru bahwa materi aspek distribusi dan gizi bukanlah ranah tugasnya. Pemerintah perlu merubah pandangan itu, meningkatkan pemahaman PPL mengenai ke dua aspek ketahanan pangan yaitu akses dan pemanfaatan pangan, dan membangun komitmen PPL dalam menjalankan tugasnya untuk mendukung perwujudan ketahanan pangan rumah tangga tani.

Penelitian inimenemukan bahwameskipersentase perempuan tani yang mengikuti kegiatan penyuluhan yang difasilitasi oleh PPL rendah, PPL merupakan penyelenggara penyuluhan terbanyak yang pernah diikuti perempuan tani (73.6 persen) dibanding oleh penyuluh swadaya (18.2 persen), kader posyandu (3.6 persen), dan petugas dari Puskesmas (3.6 persen). Ini menunjukkan peran PPL sangat strategis untuk menjadi sumber informasi bagi perempuan tani. Rendahnya persentase perempuan tani yang mengikuti kegiatan penyuluhan, disebabkan kelompok tani yang anggotanya laki-laki, dan ini sejalan dengan Hubeis (2012), pengelompokan petani berdasarkan jenis kelamin akan membatasi perempuan tani terlibat dalam kegiatan penyuluhan pertanian. Sejatinya, dalam penyelenggaraan penyuluhan, PPL berkomitmen untuk menjunjung tinggi asas kesetaraan, berkeadilan, partisipatif seperti yang tertuang pada Pasal 2 dalam Undang-undang No 16 Tahun 2006 tentang Sistem Penyuluhan Pertanian, Perikanan, dan Kehutanan. Kader Posyandu maupun petugas Puskesmas juga harus intensif memberikan penyuluhan tentang distribusi dan 
gizi pangan, bukan hanya sekedar menimbang balita dan memberikan makanan tambahan.

Peluang untuk mendapatkan pangan dimiliki oleh perempuan tani, karena sebanyak 77 persen berpengalaman dalam berusaha tani dan jumlah tanggungan keluarga tergolong kecil (85.6 persen kurang dari 4 orang). Kecenderungannya, dengan ratarata pengalaman 22 tahun, perempuan tani memiliki pengalaman yang banyak tentang pengelolaan ketahanan pangan rumah tangga.

\section{Kemampuan Sosial Ekonomi Rumah Tangga}

Rumah tangga mengelola lahan rata-rata kurang dari 0.25 ha (Gambar 2) dengan status milik dan sewa. Lahan milik digunakan untuk tanaman padi dan palawija, lahan sewa untuk tembakau. Rumah tangga juga mengusahakan tanaman sayuran, pisang dan kelapa, baik di sawah, tegalan, dan pekarangan. Bertani merupakan sumber pendapatan utama rumah tangga selain berburuh tani, berdagang, menganyam dan menjahit bagi perempuan tani; dan berburuh tani, berburuh bangunan, ngojek dan berdagang bagi laki-laki. Berdasarkan garis kemiskinan (Sajogyo 1978), pendapatan rata-rata rumah tangga tergolong cukup (Rp3 708 628.25/kapita/tahun). Pendapatan perempuan tani yang tergolong rendah telah berkontribusi sebesar 15.08 persen. Seluruh pendapatan perempuan tani digunakan untuk memenuhi kebutuhan pangan rumah tangga, dan ini sejalan dengan pendapat Hubeis (2012) dan Elizabeth (2008). Rendahnya pendapatan perempuan tani terkait dengan jenis pekerjaan dan upah yang terkadang lebih rendah dari laki-laki.

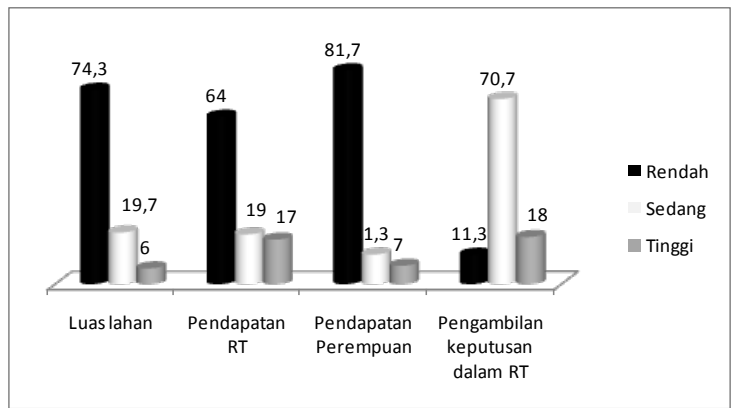

Gambar 2. Sebaran perempuan tani menurut kemampuan sosial ekonomi rumah tangga perempuan tani di Lombok Timur

Pengambilan keputusan yang terjadi sangat terkait dengan pembagian kerja berdasarkan gender dan alokasi kekuasaan dalam rumah tangga. Laki-laki dominan pada aspek ketersediaan pangan yaitu menentukan jenis tanaman, cara bertani, beternak, pemasaran hasil panen dan penggunaannya, serta menyimpan hasil panen. Perempuan tani lebih dominan, pada penentuan jenis pangan dan pemenuhan kebutuhan gizi. Perempuan tani juga menentukan pendistribusian makanan, penggunaan pendapatannya dan pendapatan suami untuk kebutuhan pangan rumah tangga, pembelian bahan pangan di pasar atau warung, serta pengambilan bahan pangan di sawah atau pekarangan. Hal ini serupa dengan yang dijumpai Ibnouf (2009) di Sudan bahwa perempuan tani lebih rasional dalam memutuskan pengalokasian pendapatan untuk pemenuhan kebutuhan pangan rumah tangga.

\section{Sosial Budaya Masyarakat}

Perwujudan ketahanan pangan rumah tangga membutuhkan dukungan keluarga, kelompok, tokoh masyarakat, nilai budaya yang berlaku, dan kondisi yang adil jender. Dukungan keluarga terutama suami tergolong rendah (Gambar 3). Suami menyerahkan sepenuhnya kepada perempuan tani. Suami tidak memiliki pemahaman yang benar mengenai distribusi makanan, memilih jenis pangan, penyediaan pangan bergizi dan manfaatnya bagi kesehatan. Suami juga tidak memahami pentingnya perempuan tani mengikuti kegiatan penyuluhan. Pandangan PPL dan masyarakat bahwa kegiatan produksi pertanian merupakan tanggung jawab suami dan hanya tepat untuk suami, maka penyuluhan oleh PPL yang materinya selalu mengenai kegiatan produksi hanya dihadiri oleh suami.

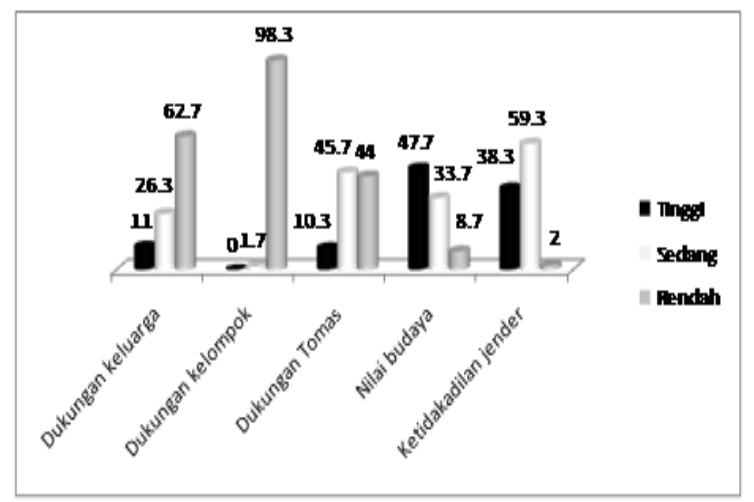

Gambar 3. Sebaran perempuan tani menurut daya dukung sosial budaya masyarakat di Kabupaten Lombok Timur

Umumnya, semua kelompok yang ada kurang mendukung perempuan tani dalam mewujudkan ketahanan pangan. Semua kelompok belum menyadari pentingnya perwujudan ketahanan pangan rumah tangga. Hampir semua anggota kelompok tani adalah laki-laki, sedangkan keanggotaan dalam kelompok wanita tani bias elit. Dukungan tokoh masyarakat ada, namun lemah. Tokoh masyarakat, khususnya tokoh adat atau agama berpandangan bahwa perannya tidak mengurusi pangan rumah tangga, meskipun hubungan perempuan tani dengan tokoh masyarakat informal sangat baik. Nilai budaya yang berlaku pun tidak menghambat perempuan tani dalam mewujudkan ketahanan pangan rumah tangga. Kondisi ini berbeda dengan penelitian Oladejo et al. (2011) di Nigeria yang menemukan masih banyak dijumpai "Taboo" bagi perempuan tani untuk melakukan kegiatan dalam produksi pangan dan mengikuti kegiatan penyuluhan. Persoalannya, ada ketidakadilan gender di masyarakat. Perempuan tani hanya dipandang sebagai pencari nafkah tambahan buat keluarga sekalipun kontribusinya tinggi. Upah harian perempuan tani lebih rendah dari laki-laki. Sebagai contoh, upah perempuan tani untuk pekerjaan yang sama sebesar Rp25 000/hari, sedangkan laki-laki Rp. 40 000/hari.

\section{Akses Perempuan tani terhadap Sumber Daya Produktif Gambar 4 memperihatkan perempuan tani cukup} akses terhadap lahan sawah yang dikelola rumah tangga 
meskipun lahan tersebut milik suami. Bersama suami, perempuan tani mengusahakan pangan untuk kebutuhan rumah tangga. Kondisi ini mendukung pendapat bahwa umumnya di banyak negara berkembang, meski perempuan tani merupakan produsen penting dan aktif dalam mewujudkan ketahanan pangan rumah tangga, perempuan tani cenderung tidak memiliki tanah untuk ditanami dan biasanya hanya menikmati hak guna lahan milik keluarganya (Prakash 2003; World Bank 2009; Brown et al. 2001; Mudukuti dan Miller 2002). Cukup tingginya akses perempuan tani terhadap lahan tidak berarti mudah mendapatkan kredit. Hanya perempuan tani pemilik lahan yang berstatus janda dan anggota kelompok saja yang punya akses terhadap kredit. Artinya, lemahnya hak perempuan tani atas tanah telah mengakibatkan sulitnya mereka mendapatkan akses kredit. Akses yang sama antara laki-laki dan perempuan tani terhadap kredit mencapai hasil yang sama (Oladejo et al. 2011; Damisa et al. 2007). Bagi perempuan tani yang berusaha sebagai penjahit dan pedagang, kredit diperoleh dari "bank rontok" (rentenir) yang tak memerlukan agunan dan sangat cepat prosesnya, tapi berbunga tinggi.

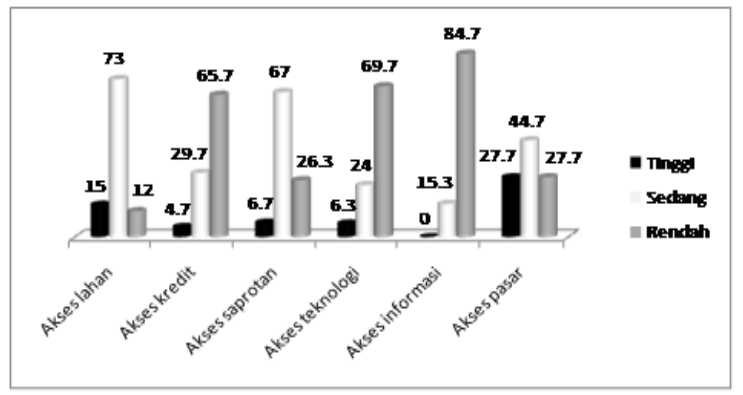

Gambar 4. Sebaran perempuan tani menurut akses terhadap sumber daya produktif di Kabupaten Lombok Timur

Gambar 4 juga memperlihatkan akses perempuan tani terhadap sarana produksi pertanian relatif kuat. Hal ini terjadi karena penanaman, penyiangan dan pemupukan banyak dilakukan kaum perempuan tani. Jika perempuan tani diberikan akses yang sama dengan laki-laki terhadap sarana produksi pertanian, dapat memberikan hasil yang sama (Bachelet 2011; Emma 2008; Damisa et al. 2007). Informasi dan teknologi tepat guna terkait kegiatan pertanian dan non pertanian, serta dalam rangka proses alih teknologi sangat penting bagi perempuan tani. Saat ini akses tersebut masih terbatas. Banyaknya hambatan komunikasi telah mengakitbatkan minimnya informasi tentang ketahanan pangan yang diperoleh kaum perempuan tani. Perempuan tani relatif tinggi aksesnya terhadap pasar, terutama berkaitan dengan penyediaan (belanja) kebutuhan panen.

\section{Dukungan Penyelenggaraan Penyuluhan Ketahanan Pangan}

Umumnya, perempuan tani memandang bahwa penyelenggaraan penyuluhan belum mendukung mereka dalam mewujudkan ketahanan pangan rumah tangga meskipun perempuan tani memandang penyuluh sebagai petugas yang memiliki kapasitas yang cukup memadai untuk melakukannya (Gambar 5).

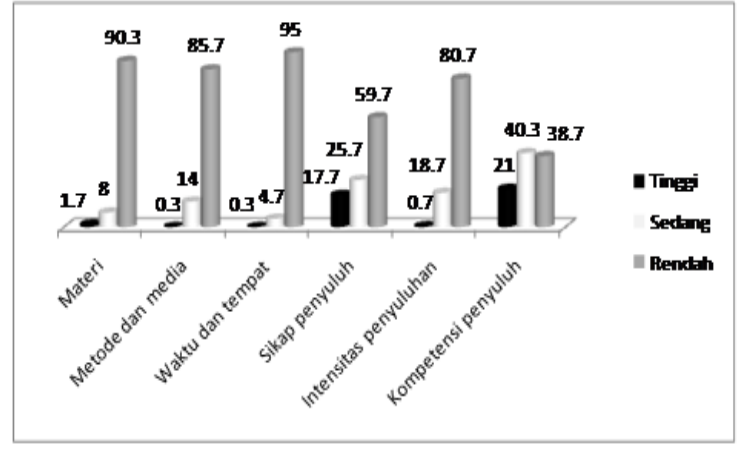

Gambar 5. Sebaran pandangan perempuan tani tani terhadap penyelenggaraan penyuluhan di Kabupaten Lombok Timur

Materi ketahanan pangan tidak menjadi prioritas dalam penyuluhan (90.3 persen). Penyuluh sangat jarang membahas pangan dari sisi off farm. Karena demikian, maka metode dan media apapun yang digunakan tetap tidak berarti (85.7 persen) bagi perempuan tani. Waktu dan tempat penyuluhan juga tidak memberi kesempatan kepada perempuan tani ( 95 persen). Karena penetapannya tidak disepakati bersama dan tidak sesuai dengan kesibukan perempuan tani, sehingga pelayanan penyuluh bias laki-laki dan frekuensi interaksi penyuluh dengan perempuan tani menjadi rendah.

\section{Tingkat Kemampuan Perempuan tani dalam Men-} dukung Ketahanan Pangan Rumah Tangga

Kemampuan perempuan tani untuk mendukung ketahanan pangan rumah tangga disajikan dalam Gambar 6. Perempuan tani tani belum memiliki kemampuan yang memadai untuk mendukung ketahanan pangan rumah tangga. Perempuan tani tani memiliki kemampuan teknis yang relatif lebih tinggi dibandingkan dengan kemampuan manajerial dan sosial. Kecenderungannya, perempuan tani tani memiliki kemampuan (aspek pikomotor) yang lebih rendah dari aspek pemahaman (aspek kognitif) dan sikapnya (aspek afektif). Artinya, perempuan tani tani memiliki pemahaman (aspek kognitif) yang rendah mengenai cara produksi pangan dan diversifikasi pangan, cara memperoleh pangan, cara melakukan kegiatan diversifikasi konsumsi pangan serta penyediaan pangan berkualitas, memiliki minat untuk menerapkannya, tetapi tidak memiliki kemampuan untuk menerapkannya.

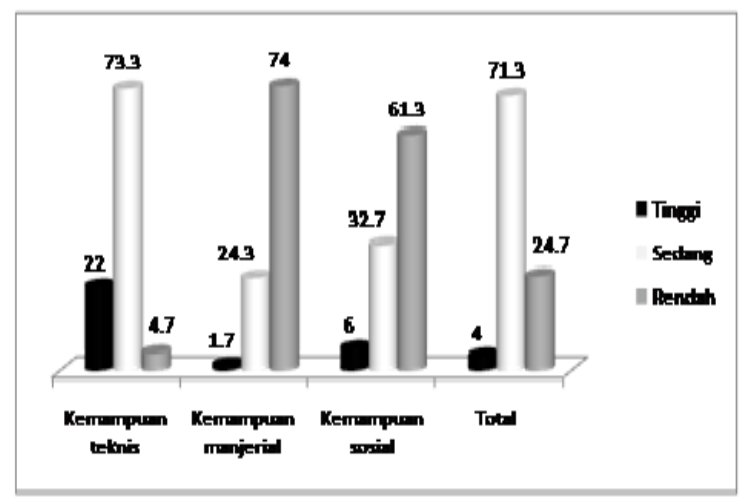

Gambar 6. Sebaran perempuan tani menurut tingkat kemampuan perempuan tani dalam mewujudkan ketahanan pangan di Kabupaten Lombok Timur 
Tabel 1. Koefisien korelasi antara profil pribadi, sosial ekonomi rumah tangga, sosial budaya masyarakat, akses sumber daya, dan penyelenggraaan penyuluhan dengan kemampuan perempuan tani di Kabupaten Lombok Timur

\begin{tabular}{|c|c|c|c|}
\hline \multirow{2}{*}{ Profil perempuan tani } & \multicolumn{3}{|c|}{ Koefisien korelasi } \\
\hline & Kemampuan teknis & Kemampuan manajerial & Kemampuan sosial \\
\hline \multicolumn{4}{|l|}{ Pribadi perempuan tani } \\
\hline Usia & .089 & -.050 & .007 \\
\hline Pendidikan formal & .026 & .018 & -.077 \\
\hline Pendidikan non formal & $.260 * *$ & .060 & $.119^{*}$ \\
\hline Pengalaman bertani & .037 & -.043 & -.004 \\
\hline Tanggungan keluarga & .090 & .100 & .093 \\
\hline Motivasi & $.328^{* *}$ & $.444 * *$ & $.471^{* *}$ \\
\hline \multicolumn{4}{|l|}{ Sosial ekonomi rumah tangga } \\
\hline Luas lahan & $.196^{* *}$ & $.136^{*}$ & $.169^{* *}$ \\
\hline Pendapatan rumah tangga & .095 & 055 & 056 \\
\hline Pendapatan perempuan tani & .028 & .009 & .009 \\
\hline Pengambilan keputusan dalam keluarga & $.197^{* *}$ & $.123^{*}$ & $.190^{* *}$ \\
\hline \multicolumn{4}{|l|}{ Sosial budaya masyarakat } \\
\hline Dukungan keluarga & $.412 * *$ & $.342 * *$ & $.470 * *$ \\
\hline Dukungan kelompok & -.005 & -.026 & -.038 \\
\hline Dukungan tokoh masyarakat & .087 & $.145^{*}$ & .064 \\
\hline Nilai budaya & $.330^{* *}$ & $.230^{* *}$ & $.322^{* *}$ \\
\hline Keadilan Gender & $.283^{* *}$ & $.155^{* *}$ & $238^{* *}$ \\
\hline \multicolumn{4}{|l|}{ Akses terhadap sumber daya } \\
\hline Akses terhadap lahan & $.126^{*}$ & $.207^{* *}$ & $.195^{* *}$ \\
\hline Akses terhadap kredit & -.089 & $.201 * *$ & 089 \\
\hline Akses terhadap input pertanian & .044 & $.158^{* *}$ & $.122 *$ \\
\hline Akses terhadap teknologi & .104 & $.255^{* *}$ & $.272 * *$ \\
\hline Akses terhadap informasi & $.332 * *$ & $.416^{* *}$ & $.438 * *$ \\
\hline Akses terhadap pasar & $.158 * *$ & $.122 *$ & $.135^{*}$ \\
\hline \multicolumn{4}{|l|}{ Penyelenggaraan penyuluhan } \\
\hline Materi & $.167^{* *}$ & $.218^{* *}$ & $.223 * *$ \\
\hline Metode dan media & $.360^{* *}$ & $.287 * *$ & $.405 * *$ \\
\hline Waktu dan tempat & .103 & .098 & $.184 * *$ \\
\hline Sikap penyuluh & $.445^{* *}$ & $.386^{* *}$ & $.557 * *$ \\
\hline Intensitas penyuluhan & $.276^{* *}$ & $.371 * *$ & $.373 * *$ \\
\hline Kompetensi penyuluhan & $.388 * *$ & $.306^{* *}$ & $.457 * *$ \\
\hline
\end{tabular}

Keterangan: **) Nyata pada $\alpha=0.01$; dan *) Nyata pada $\alpha=0.05$

Kemampuan sebagai kecakapan individu yang dimiliki seseorang dapat dibawa sejak lahir atau hasil pelatihan atau praktik yang digunakan untuk berbagai tugas melalui suatu tindakan (Robbins 2003). Kemampuan teknis pada aspek ketersediaan pangan diperoleh perempuan tani melalui pendidikan informal dari suami, orang tua, keluarga, tetangga atau petani lain, bukan melalui pendidikan non formal/penyuluhan/ pelatihan dari penyuluh. Sejak remaja, perempuan tani biasa menanam di sawah/tegalan/lahan pekarangan, berburuh tani. Kemampuan teknis mengenai akses pangan dan pemanfataan pangan diperolehnya dari orang tua (terutama ibu) sejak remaja, seperti kebiasaankebiasaan membuat kerajinan tangan dari bambu untuk mendapatkan uang; bagaimana memperoleh pangan; dan bagaimana mengolah, menyediakan, dan mendistribusikan pangan bagi anggota rumah tangga.
Kegiatan-kegiatan itu merupakan kegiatan yang rutin dilakukan perempuan tani. Kondisi ini menguatkan berlakunya stereotipe peran gender bahwa perempuan tani adalah orang yang bertanggungjawab terhadap pelaksanaan kegiatan reproduksi sosial (pemelihara keluarga), pengurus rumah tangga yang kompeten dan rajin (William 1987).

Lemahnya kemampuan manajerial dan kemampuan sosial perempuan tani tani disebabkan oleh terbatasnya kesempatan belajar dan praktik baik melalui pendidikan informal dari keluarga dan masyarakat, maupun non formal (penyuluhan/pelatihan) dari pemerintah. Secara manajerial, perempuan tani belum mampu merencanakan, mengatur, menggerakkan/mengarahkan dan mengevaluasi pelaksanaan kegiatan ketahanan pangan rumah tangga. Perempuan tani belum mampu menyiapkan dana, mengidentifikasi permasalahan sosial 
dan manfaat makanan berkualitas bagi kehidupan setiap anggota rumah tangga, mengalokasikan sumberdaya dan fasilitas, mengambil keputusan penting, melakukan pengadministrasian usaha, menyusun laporan keuangan dan rencana kegiatan rumah tangga di masa depan. Secara sosial, perempuan tani belum mampu berkomunikasi dan bekerjasama dalam kelompok, bernegosiasi, membangun jaringan kerja dan usaha dalam rangka mewujudkan ketahanan pangan rumah tangga. Perempuan tani masih banyak yang belum terlibat dan aktif dalam kelompok tani dan organisasi masyarakat. Kelompok perempuan tani yang ada (PKK) bias elit desa dan programnya mengenai pangan dan gizi melalui kegiatan posyandu, hanya menyentuh ibu hamil dan menyusui. Program dari Badan Ketahanan Pangan, Kabupaten Lombok Timur yang diperuntukkan kelompok wanita tani, sasarannya bias elit desa dan materinya juga tidak menyentuh sama sekali aspek pangan dan gizi. Kelompok lain yang ada, misalnya "Banjar" juga belum dimanfaatkan sebagai wadah belajar bagi perempuan tani untuk mewujudkan ketahanan pangan rumah tangga. Kelompok dapat dijadikan media belajar dan bekerja sama antar sesama perempuan tani tani terkait dengan perwujudan ketahanan pangan rumah tangga. Temuan penelitian di India bahwa pembentukan dan pengembangan kelompok atau organisasi perempuan tani adalah kunci untuk meningkatkan ketahanan pangan rumah tangga (Ramakrishna et al. 2012). Oleh karena itu, perwujudan ketahanan pangan rumah tangga tani dapat dilakukan dengan membentuk dan mengembangkan kelompok atau organisasi bagi perempuan tani tani.

\section{Hubungan Profil Pribadi Perempuan tani, Sosial Ekonomi Rumah Tangga, Sosial Budaya Masyarakat, Akses terhadap Sumber Daya dan Penyelenggaraan Penyuluhan dengan Tingkat Kemampuan Perempuan tani}

Tabel 1 memberikan makna bahwa mengikut sertakan perempuan tani dalam penyuluhan akan meningkatkan kemampuan teknis dan kemampuan sosial, dan meningkatkan motivasi perempuan tani akan meningkatkan kemampuan teknis, manajerial dan sosialnya. Luas lahan dan pengambilan keputusan dalam rumah tangga jika ditingkatkan juga akan meningkatkan kemampuan perempuan tani dalam mendukung ketahanan pangan rumah tangganya, baik kemampuan teknis, manajerial maupun sosial.

Perempuan tani juga akan dapat mengembangkan kemampuannya baik secara teknis, manajerial maupun sosial, jika ada dukungan yang tinggi dari keluarga terutama suami; jika budaya mendorong perempuan tani untuk berpartisipasi dalam penyuluhan, untuk berkomunikasi dan berkelompok; dan jika terdapat kondisi yang adil jender, terutama dalam pembagian kerja dan tingkat upah.

Akses yang tinggi terhadap sumber daya lahan, informasi dan pasar akan mengembangkan ke tiga kemampuan perempuan tani, yaitu kemampuan teknis, manajerialdansosial.Perempuantanimemilikikemampuan yang memadai dalam melakukan budidaya tanaman pangan, memperoleh pangan dan mendistribusikan makanan yang berkualitas kepada anggota rumah tangga.
Hal ini sejalan dengan temuan World Bank (2009) bahwa produksi yang tinggi akan meningkatkan ketersediaan pangan untuk konsumsi rumah tangga, Hubeis (2012) bahwa ketidaktahuan dan ketidakmampuan perempuan tani mengaskses informasi pertanian terkini sering menghambat kemajuan perempuan tani dan kontribusi mereka pada ketahanan pangan rumah tangga.

Secara keseluruhan, positifnya pandangan perempuan tani terhadap penyelenggaraan penyuluhan dapat mengembangkan kemampuan teknis, manajerial dan sosial perempuan tani. Penyelenggaraan penyuluhan ketahanan pangan merupakan kebutuhan. Diperlukan kesesuaian materi, metode dan media, waktu dan tempat penyuluhan bagi perempuan tani, serta sikap penyuluh yang positif, tingginya intensitas penyuluhan dan kompetensi penyuluh agar kemampuan perempuan tani memadai untuk mewujudkan ketahanan pangan rumah tangga.

\section{SIMPULAN}

Karakteristik pribadi dan kondisi sosial ekonomi rumah tangga tergolong rendah, kecuali motivasi dan peran perempuan tani dalam pengambilan keputusan. Secara sosial budaya, kesadaran masyarakat akan pentingnya mencapai KPRT juga tergolong rendah, termasuk kondisi keadilan gender dan dukungan penyelenggaran penyuluhan. Meskipun kemampuan teknis perempuan tani lebih baik dari pada kemampuan manajerial dan kemampuan social, secara umum kemampuan perempuan tani tergolong masih kurang memadai untuk mendukung terwujudnya ketahanan pangan rumah tangga.Faktor-faktor yang berhubungan positif dan nyata dengan kemampuan perempuan tani menunjukkan bahwa semakin tinggi tingkat pendidikan non formal, motivasi, tanggungan keluarga, luas lahan yang dikelola rumah tangga, pengambilan keputusan oleh perempuan tani dalam rumah tangga, dukungan keluarga, nilai budaya dan keadilan jender, akses perempuan tani terhadap lahan, teknologi, informasi dan pasar, penilaian perempuan tani terhadap materi, metode dan media, waktu dan tempat penyuluhan, serta sikap penyuluh, intensitas penyuluhan dan kompetensi penyuluh akan meningkatkan tingkat kemampuan teknis, manajerial dan sosial perempuan tani.

\section{DAFTAR PUSTAKA}

Arumsari, V., \& Rini, W.D.E. 2008. Peran Perempuan tani dalam Mewujudkan Ketahanan Pangan pada Tingkat Rumahtangga di Kabupaten Sleman Daerah Istimewa Yogyakarta. Jurnal Ekonomi Pembangunan, 13(1), 71-82. http://journal.uii. ac.id/index.php/JEP/article/view/52

Bachelet, M. 2011. Empowering Rural Women and Food Security. Pidato dan Laporan Direktur Eksekutif Perempuan tani PBB pada acara Dialog Terbuka tentang Pemberdayaan Perempuan tani Pedesaan serta Ketahanan Pangan dan Gizi. New York, 22 September. http://www.unwomen.org/2011/09/ empowering-rural-women-and-foodsecurity/ 
Brown, L.R., Feldstein, H., Haddad, L., Pena, C., \& Quisimbing, A. 2001. Generating Food Security in the Year 2020: Women as Producers, Gatekeepers, and Sock Absorbes. Di dalam: The Unfinished Agenda: Perspective on Overcoming Hunger, Poverty, dan Environmental. Washington DC: International Food Policy Research Institute.

Damanik, I.P.N. 2014. Penguatan Kapasitas Pengolah Sagu Tradisional untuk Mendukung Diversifikasi Pangan di Maluku. Ph.D. Disertasi. Institut Pertanian Bogor, Bogor.

Damisa, M.A., Samndi, R., \& Yohanna, M. 2007. Women Participation in Agricultural Production: A Probit Analysis. Journal of Applied Science, 7(3),412-416. http://adsabs.harvard.edu $a b s / 2007 J A p S c . . .7 . .412 D$.

Elizabeth,R.2008.Peran GandaWanita TanidalamMencapai Ketahanan Pangan Rumah Tangga di Pedesaan. Iptek Tanaman Pangan, 3(1), 59-68. http://pangan.litbang. deptan.go.id/test.php?folder $=$ files \&filename $=05$ Roosganda\&ext $=$ pdf

Emma, A. 2008. Factsheet: Women's farmers and Food Security. The Hunger Project. Union Square West. New York, NY 10003. http://www.thp.org/

Firmansyah, Afzalani, Farhan, M. 2010. Keaneka-ragaman dan Kecukupan Konsumsi Pangan Hewani dalam Hubungannya dengan Kualitas Sumberdaya Manusia Keluarga di Provinsi Jambi. Jurnal
Penelitian Universitas Jambi: Seri Humaniora, 12(1), 63-70. http://online-journal.unja.ac.id/index. php/humaniora/article/view/215/191

Mudukuti, A.E., \& Miller, L. 2002. Factors Related to Zimbabwe Women's Educational Needs in Agriculture. Journal of International Agricultural and Extension Education, 9(3).http://www.aiaee. org/.

Ramakrishna, R., Subbarao, N., Chiranjeevi, Ch. 2013. Role of Women in Improving Household Food Security in India. Indian Journal of Agricultural Economics, 67(3):525-526.http://search.proquest. com/docview/1239040339?accountid=32819

Sajogyo. 1978. Golongan Miskin di Pedesaan. Di dalam: Kemiskinan Di Tengah Deru Pembangunan. Bandung: Pustaka.

Sumardjo. 1999. Transformasi model penyuluhan pertanian menuju pengembangan kemandirian petani (kasus di Propinsi Jawa Barat). Ph.D. Disertasi. Institut Pertanian Bogor, Bogor.

Suprapto, A. 2010. Menuju Profesionalisme Penyuluh Pertanian. Di dalam: Peran Strategis Penyuluhan Pertanian dalam Mendukung Ketahanan Pangan. Ekstensia. Ed ke-1.

Yunita. 2011. Strategi Peningkatan Kapasitas Petani Padi Sawah Lebak Menuju Ketahanan Pangan Rumah Tangga di Kabupaten Ogan Ilir dan Ogan Komering Ilir Provinsi Sumatera Selatan. Ph.D. Institut Pertanian Bogor, Bogor. 